\title{
Are foreign firms favored in China? Firm-level evidence on the collection of value-added taxes
}

\author{
Yasheng Huang ${ }^{1}$ and \\ Heiwai Tang ${ }^{2}$
}

${ }^{7}$ MIT Sloan School of Management, E62-462,
100 Main Street, Cambridge, MA 02142, USA;
${ }^{2}$ School of Advanced International Studies, Johns
Hopkins University, 1717 Massachusetts Ave NW,
Suite 709,, Washington, DC 20036, USA

Correspondence:

Y Huang, MIT Sloan School of Management, E62-462, 100 Main Street, Cambridge, MA 02142, USA e-mail: yshuang@mit.edu
Received: 2 November 2017

Revised: 26 March 2018

Accepted: 27 March 2018

Online publication date: 9 May 2018

\begin{abstract}
Research has uncovered the so-called foreign-ownership bias in China persistent and sizable policy-induced advantages conferred on foreign firms at the expense of domestic private firms. This article examines the presence of such biases in regulatory implementation, as revealed in the different actual value-added tax (VAT) incidence borne by foreign versus domestic firms. Using comprehensive Chinese manufacturing firm data, we find that within an industry, the de facto VAT rates facing foreign firms are on average 2 percentage points lower than those of domestic private firms. The finding of this "VAT discount" for foreign firms is robust to controlling for a host of firm characteristics and to using alternative definitions of foreign ownership. We rule out various economic motivations, such as the technology-seeking motive, and show indirect evidence that the ownership bias is intended to protect stateowned enterprises. Further research is needed to precisely pin down the underlying motivations and mechanisms.
\end{abstract}

Journal of International Business Policy (2018) 1, 7|-9|.

https://doi.org/| 0.1057/s422 I4-0 | 8-0006-z

Keywords: taxation; foreign direct investment policy; political economy

The online version of this article is available Open Access

If you look at the horizon and wonder what the environment will be like in 2-5 years, the implication is that the market will be narrow with China favoring domestic companies as opposed to the products and services of foreign enterprises in China. From our point of view, protection is counterproductive in the long run. (Christian Murck, President of the American Chamber of Commerce in China).

As entrepreneurs we are condemned to being either the concubines of state enterprises or the mistresses of multinationals. ( $W u$ Kegang, President of Yunnan Hong Wine, a private spirits company in southwest China) ${ }^{1}$.

\section{INTRODUCTION}

In 2016, net foreign direct investment (FDI) inflows to China amounted to US $\$ 171$ billion, compared to $\$ 44$ billion of FDI flows to India in the same year. This impressive record of FDI attraction and other open-market economic policies have been credited for contributing to the spectacular economic growth and poverty reduction in China. ${ }^{2}$ As an extensive literature on FDI argues, many of the determinants of FDI inflows to China are undoubtedly 
economic in nature, such as market size effects and competitive labor costs.

Recent studies postulate that the impressive FDI attraction in China is, at least in part, an outcome of regulations and laws designed and implemented to favor foreign-invested enterprises (FIEs). ${ }^{3}$ Specifically, these studies argue that China's FDI inflows are heavily conditional on the institutional landscape, which manifests a political pecking order of firms. State-owned enterprises (SOEs) stand at the top of the pecking order, whereas domestic private firms are at the bottom. In the middle of the pecking order are the FIEs. A revealed outcome of the pecking order is that FIEs are systematically favored by the government over domestic private firms through both the design and implementation of laws and regulations.

This "foreign-ownership bias" view, derived from an institutional analysis of China, contrasts sharply with what is commonly known as "liability of foreignness" view held widely by scholars in international business studies and by some business practitioners. ${ }^{4}$ Liability of foreignness is formally defined by Zaheer (1995: 342-343) as "[a]ll additional costs a firm operating in a market overseas incurs that a local firm would not incur." There are many forms of this liability on the part of foreign firms. For example, foreign firms can be disadvantaged in terms of their lack of knowledge about local market and institutional and cultural environment; or they can be disadvantaged deliberately by host governments wishing to promote the interests of local firms at the expense of foreign firms. ${ }^{5}$

The views expressed by a foreign investor and a domestic entrepreneur, quoted at the beginning of this article, represent two sharply divergent views on the business environment in China. The foreign investor's opinion is consistent with the liability of foreignness view, whereas the view of the domestic entrepreneur is consistent with the "foreign-ownership bias" view being formulated by institutional scholars such as Huang (2003).

Our article builds on but takes further this line of research. One innovation of our article is that we show evidence on "the revealed preferences" of the Chinese government on foreign vis-à-vis domestic private firms. We demonstrate the presence of foreign-ownership bias in the area of the valueadded tax (VAT) liabilities of foreign vis-à-vis domestic firms.

This VAT focus is not a mere extension or a replication of previous research. VAT rates are statutorily uniform between foreign and domestic firms. Previous research has focused on the statutory differences in the policy and regulatory treatments between foreign and domestic firms. A VAT discount on foreign firms, i.e., lower liabilities of VAT by foreign firms than domestic firms, is evidence of deeper, more pervasive, and more systemic advantages enjoyed by foreign firms as compared with domestic firms than has been shown by previous research.

The purpose of this article is threefold. First, we provide more rigorous evidence based on micro data and on fuller specifications of firm behavior to validate previous findings on foreign-ownership biases based on case analytics and more macro data. Second, we investigate how the degree of the VAT biases varies across sectors and provincial administrative regions to gain an understanding of the determinants of the biases. Third, we offer a conjecture, based on suggestive evidence, about why such a foreign-ownership bias exists in the Chinese economy.

It is important to note a number of limitations of our study. First, our dataset covers the period from 1998 to 2005. This is in large part dictated by data availability. The data come from the annual census data on the above-scale Chinese manufacturing firms (more details provided later in the article). The dataset contains rich and detailed information on foreign and domestic firms. The disadvantage is that the Chinese government often changed the data and variable coverage from year to year. We chose the period from 1998 to 2005 in part because data on a number of key variables used in our regressions during this period have the highest level of intertemporal consistency.

Thus, our findings should be confined to the period before and right after China's accession to the World Trade Organization (2001). In recent years (since the ascendency of Xi Jinping in 2013), there have been increasing and more vocal concerns by foreign businesses about a deterioration of China's business environment. Our empirical coverage does not allow us to formulate an informed view of how foreign businesses have fared during this period. It should be noted that during the Xi Jinping era, there have been substantial complaints and outright exits by domestic private businesses as well. In 2016, for example, fixed asset investments made by domestic private firms grew at a lower rate compared with firms of other ownership types, reflecting a pessimistic outlook on the part of domestic private firms we have not seen for years. Because our methodology is a systematic comparison of foreign businesses with domestic businesses, 
the vocality of concerns on the part of foreign businesses is not ipso facto an invalidation of an extrapolation of our findings to the current period.

The second limitation of our study is that the main empirical analysis is to demonstrate the existence (or lack thereof), rather than the motivations, of foreign-ownership biases. This demonstration itself is already a contribution to the FDI literature related to China. We will also attempt to determine the sources of the foreign-ownership biases but our efforts here are severely hampered by data limitations. To demonstrate the motivations behind foreign-ownership biases ultimately requires data on the political and policy objectives of the Chinese government, which are unavailable to the researchers. The best we can do is to rule out a number of economic explanations for which we do have some solid data and to offer a conjecture as to the likely motivation behind the observed VAT biases. We hope that our research will help open up new areas of research and with better data, researchers will be able to conduct research on questions we are not able to in this article.

We focus on an area where FIEs and domestic firms are subject to identical statutory laws and regulations. This is the value-added tax (VAT) policy. The VAT, unlike the corporate income tax, is statutorily fixed at $17 \%$ for all firms in China. There are some exemptions or reductions for very small businesses but these businesses are not included in our dataset, which includes only medium-sized to large firms (the so-called "abovescale" firms that generate annual sales in excess of 5 million yuan). To circumvent the effects of tax incentives regarding export promotion, in our empirical analysis we also control for the firm's export participation and intensity.

By contrast, corporate income tax rates explicitly differ between foreign and domestic firms. As a rule of thumb, before the tax unification in 2006 FIEs were taxed at $15 \%$ of the corporate profit rate, whereas the rates for domestic firms ranged between 25 and 33\%. Also, various exemptions were granted to FIEs but not to domestic firms, making it difficult to compare their effective tax rates. ${ }^{6}$ Focusing on VAT collections allows us to uncover the "revealed" foreign-ownership biases in the Chinese system.

Our dataset provides information on the actual VAT liabilities of firms, which allows us to compute the effective VAT rates. This is another advantage of our study. We focus on actual policy and regulatory enforcement. A critique of the foreign-ownership bias view is that it is based on de jure features of the Chinese system. The implementation of policies and regulations can and often does systematically differ from their designs. Studying the actual tax collection obviates this problem. Evidence that VAT rates differ across different ownership types of firms is inferred as an outcome of selective execution of VAT collection. In particular, a lower de facto VAT rate for FIEs is regarded as evidence of favorable treatment by government officials. In addition, findings that show differences in this selective tax collection based on firm ownership types across provinces and industries reveal the underlying economic and political determinants of the revealed ownership biases. As far as we know, this is probably among the first articles to use actual VAT rates as a way to study policy and regulatory implementation.

Using firm-level panel data of more than 170,000 (on average) manufacturing firms in China over the 1998-2005 period, we find evidence that within a province and a highly disaggregated sector, the de facto VAT rates for foreign firms are on average 1-2 percentage points lower than those for domestic private firms and SOEs. The negative relationship between foreign ownership and the de facto VAT rates is robust to the inclusion of a range of firm-level controls, including export participation and intensity, as well as a battery of fixed effects (province, sector, and year). These results are consistent with the existence of a "foreign-ownership bias."

To preview the empirical results, Figure 1 plots the average de facto VAT rates of four groups of firms from 1998 to 2005. As shown, foreign firms with both ethnic Chinese (Hong Kong, Macau or Taiwan) investors and non-Chinese foreign investors consistently face lower de facto VAT rates than domestic firms (both SOEs and domestic private firms) over the sample period. Interestingly, the gap in the VAT rates between domestic private firms and FIEs actually widened after China entered the World Trade Organization in late 2001. Figure 2a and $b$ plots the kernel density of the distribution of the de facto VAT rates for different firm ownership types in the pooled sample. They reveal that the VAT rates for the FIEs are skewed toward 0, compared to both SOEs and domestic private firms.

There can be a myriad of reasons for why FIEs are favored by governments in developing country. To the extent that FIEs are more productive, proforeign policies and enforcement of regulations can be justified by growth-promotion motives. (In our empirical implementation, it should be noted, we control for many of the variables to control for 
Figure 1 De facto VAT rates for different ownership types. Note: The de facto VAT rate for each ownership type of firm is the average of (actual VAT payment/value-added) across all firms of the type in a year. Source: National Bureau of Statistics (NBS) of China, Annual Survey of Industrial Firms (various years).

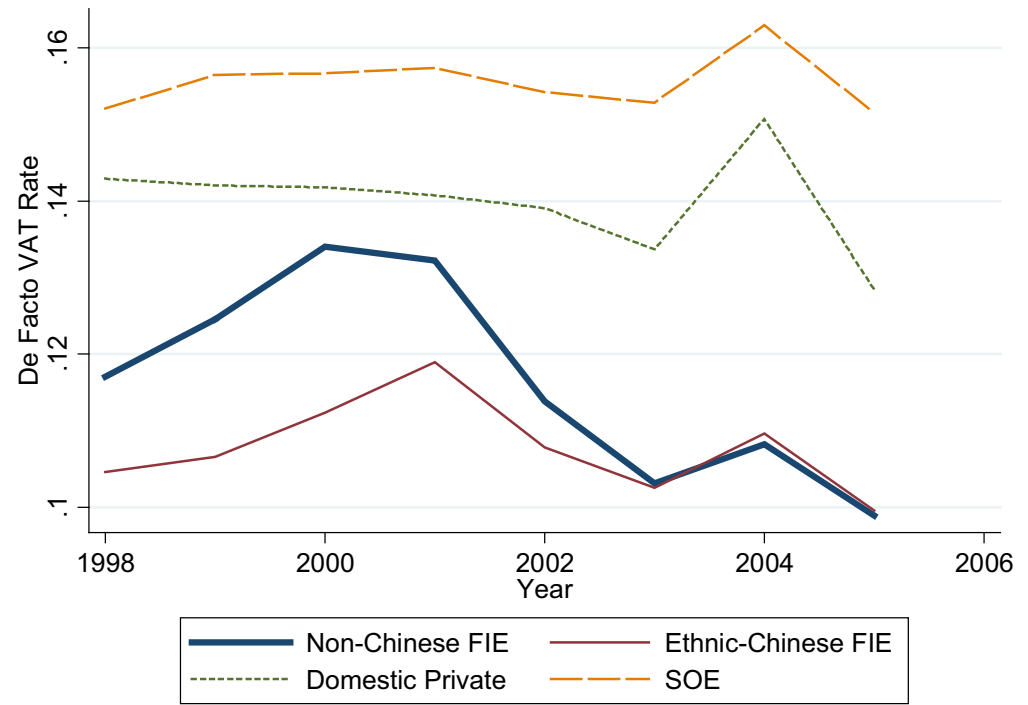

play. This is the best we can do given the data limitation.

To determine the potential economic causes of the foreign-ownership biases, we explore the variation in foreign-ownership biases across provinces and sectors. We first examine whether the prominence of SOEs in the province affects the extent of the foreign-ownership biases. Figure 3a plots the average de facto VAT rate of FIEs minus that of SOEs against the value-added share of SOEs across provinces for the year 2005. As it shows, the degree of this preferential tax treatment declines with the SOEs' value-added share across provinces, and disappears in provinces with a sufficiently high level of SOE market share.

If maximizing economic growth, driven mostly by the most dynamic private sector, is the main objective of the provincial governments, a negative relationship between the degree of foreign-ownership biases and the market share of domestic private firms across provinces is expected. As Figure $3 b$ shows, there is no significant evidence supporting this hypothesis. It is, however, worth noting that in all but four provinces in China, domestic private firms on average face a higher de facto VAT rate than FIEs. These results suggest that foreign-ownership biases against domestic private firms appear to be a national phenomenon.

It is hypothesized that when a larger share of output is exported, competition from FIEs in the product market is weakened. Thus, the negative impact and therefore the cost of ownership biases on domestic firms are mitigated. Consistent with 

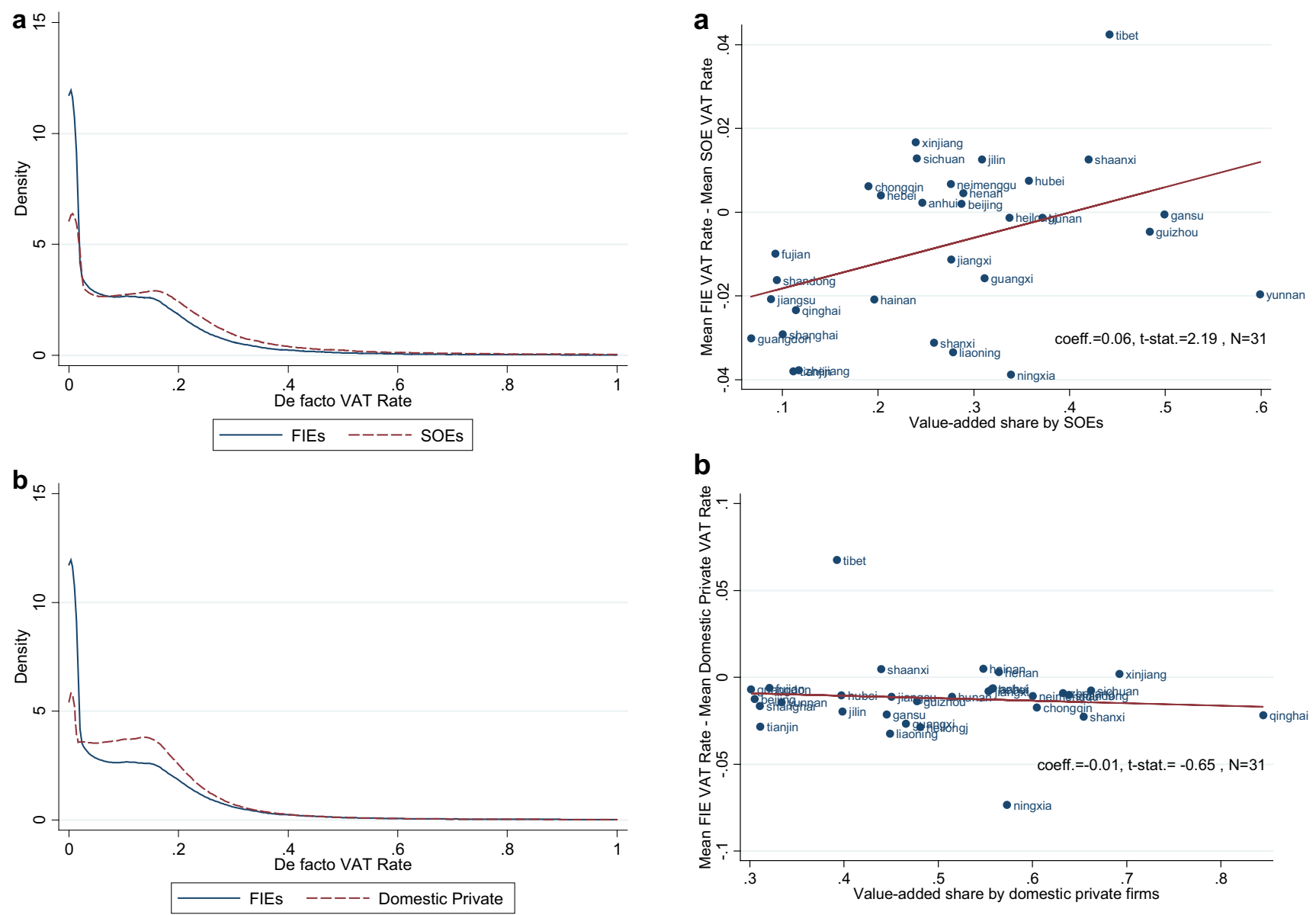

Figure 2 a Kernel density of firm VAT rates (FIEs and SOEs). b Kernel density of firm VAT rates (FIEs and domestic private firms). Source: National Bureau of Statistics (NBS) of China, Annual Survey of Industrial Firms (various years).

this hypothesis, we find stronger ownership biases favoring FIEs in more export-oriented provinces. ${ }^{8}$

Across sectors, we examine whether stronger foreign-ownership biases are found in capital-, skill-, and R\&D-intensive industries. If maximizing economic growth is the main objective of the Chinese government, we should expect stronger preferential treatment for FIEs in those sectors, based on the belief that FDI brings technology and capital to the host economy. Contrary to this argument, we find evidence that foreign-ownership biases are less pronounced in capital- and skillintensive sectors. Together with the patterns observed across provinces, our findings imply that the selective execution of VAT collection is not adopted to maximize long-term growth of the country. We offer a conjecture, based on suggestive and descriptive evidence on the differential VAT enforcements on FIE vis-à-vis SOE and domestic

Figure 3 a Mean FIE VAT rate - mean SOE VAT rate and valueadded shares of SOEs by province. b Mean FIE VAT rate - mean domestic private firm VAT rate and value-added shares of domestic private firms by province. Source: National Bureau of Statistics (NBS) of China, Annual Survey of Industrial Firms (various years).

private firms, that foreign-ownership biases are motivated by a desire to protect the less efficient SOE. (We will come back to this discussion in the concluding section of the article.)

Our empirical setting is China but the findings are related to three broad strands of literature on FDI. First, it relates to the literature on the politicaleconomic theory of economic policies. Within this literature, the seminal "Protection for Sale" (PFS) paper by Grossman and Helpman (1994) studies equilibrium levels of trade protection in an environment where the government sets trade barriers, facing a tradeoff between maximizing consumer welfare and political contributions from special interest groups in different industries. Although the paper and subsequent literature focus primarily on trade policies, the theoretical framework has been 
employed to examine governments' endogenous FDI policies (Grossman \& Helpman, 1996; Branstetter \& Feenstra, 2003). Based on an extension of the PFS model, Branstetter and Feenstra (2003) structurally estimate regional governments' objective function using province-level trade and FDI data for China. Our article complements Branstetter and Feenstra (2003). Although we do not adopt a structural approach based on the PFS framework, our empirical analysis is grounded on the same conceptual framework in which each provincial government faces a tradeoff between maximizing SOE output and output of other ownership types of firms. Based also on a lobbying framework, Chari and Gupta (2008) show that firms in more concentrated industries are more able to block foreign entry, especially when SOEs account for a higher share of output in those industries.

Our work is also related to the extensive literature about the contribution of FDI to the host economy. Within this line of research, productivity spillovers from FDI to domestic firms receive the most attention. ${ }^{9}$ The theoretical strand of this literature asserts that domestic firms can benefit from the entry of foreign firms through imitation, competition, arms-length transactions, and worker turnover (Kokko, 1996). Supporting these arguments, early empirical studies based on industry-level data find evidence of positive spillovers. ${ }^{10}$ However, recent studies based on micro-level (firms or establishments) data cast doubts on the evidence of positive spillovers, and find either insignificant or negative intra-industry spillovers. ${ }^{11}$ Our article suggests a potential research avenue to explain the missing spillover effects from FDI.

Our article also complements the literature that studies the institutional origins of FDI flows to China. Huang (2003) postulates that biases in the design and execution of policies and regulations favor foreign firms at the expense of domestic private firms. Using the same dataset as in this article, Huang, Ma, Yang, and Zhang (2016) demonstrate the effects of capital-market distortions on FDI inflows to China and shed light on the prevalence of FDI in labor-intensive industries in China. They argue that under the dualist legal and financial institutions that favor foreign firms and SOEs, domestic private firms find it difficult to borrow in the domestic credit market dominated by state-owned banks. In this situation, foreign equity provides a feasible source of financing to the financially strapped domestic private firms. Consistent with this argument, Guariglia and Poncet
(2008) provide evidence to show that financial constraints on domestic private firms act as a "pull" factor for FDI. Further evidence on the pull factor for FDI is also provided in Huang, Ma, Yang, and Zhang (2016) in a paper that studies formation of joint ventures in textile industry in the presence of severe financing constraints.

The article is organized as follows. The next section describes the empirical framework and data source for our study. The third section presents the empirical evidence on the foreign-ownership biases. The fourth section explores the determinants of the biases. The final section concludes by offering some simple conjectures why the Chinese government favored foreign firms during this period.

\section{EMPIRICAL ANALYSES}

Our empirical analysis aims to show a deeper foreign-ownership bias arising not only from differences in official tax rates, but from the selective enforcement of laws and regulations by the Chinese government. In particular, we empirically examine the relationship between foreign ownership and de facto VAT incidence. We infer the difference in the de facto VAT rates between foreign and domestic firms as biased implementation of laws and policies. Furthermore, exploring the variations in the de facto VAT rates across provinces and sectors may help us uncover some of the hidden patterns behind foreign-ownership biases.

\section{Data and Measurement}

We use firm-level panel data from the National Bureau of Statistics of China (NBSC) to conduct our empirical analysis. The dataset contains annual census data of the population of manufacturing firms in China with sales over 5 million yuan (about US\$600,000) in each year between 1998 and 2005. The original data cover on average 190,000 firms per year. ${ }^{12}$ It is estimated that the dataset covers about $85-90 \%$ of the total value-added in most manufacturing industries, and about $20 \%$ of urban employment, ${ }^{13}$ and provides the foundation for the computation of the country's GDP and other key macroeconomic variables by the NBSC. In our analyses, we use a subsample of the dataset of manufacturing firms with at least five workers in each year in the panel. ${ }^{14}$ We drop observations with negative values for the key variables. ${ }^{15}$ After removing the unusable observations, the final unbalanced panel contains 1,519,504 observations. ${ }^{16}$ 
Table 1 Shares of value-added and number of firms by ownership types

\begin{tabular}{|c|c|c|c|c|c|c|}
\hline Year & State & Domestic private & Foreign (non-HMT) & HMT & Mixed & Collective \\
\hline \multicolumn{7}{|c|}{ Panel A: share in national value-added (in \%) } \\
\hline 1998 & 25.54 & 20.07 & 11.59 & 14.20 & 1.87 & 26.58 \\
\hline 1999 & 23.05 & 24.95 & 12.33 & 14.37 & 1.77 & 23.36 \\
\hline 2000 & 19.59 & 31.25 & 13.55 & 14.02 & 1.55 & 19.85 \\
\hline 2001 & 15.79 & 41.34 & 12.73 & 13.45 & 1.25 & 15.27 \\
\hline 2002 & 12.73 & 44.41 & 14.24 & 15.13 & 1.00 & 12.30 \\
\hline 2003 & 9.57 & 50.52 & 14.99 & 14.45 & 0.84 & 9.46 \\
\hline 2004 & 7.13 & 56.72 & 16.85 & 13.20 & 0.52 & 5.49 \\
\hline 2005 & 5.54 & 59.79 & 16.28 & 12.81 & 0.42 & 4.78 \\
\hline \multicolumn{7}{|c|}{ Panel B: number of firms } \\
\hline 1998 & 44,117 & 29,086 & 15,274 & 10,423 & 2,774 & 43,209 \\
\hline 1999 & 39,525 & 35,873 & 15,335 & 10,761 & 2,578 & 38,447 \\
\hline 2000 & 32,187 & 47,287 & 16,042 & 11,564 & 2,332 & 33,938 \\
\hline 2001 & 23,953 & 65,400 & 17,369 & 12,453 & 1,979 & 26,932 \\
\hline 2002 & 21,065 & 81,792 & 19,070 & 14,532 & 1,742 & 24,166 \\
\hline 2003 & 15,913 & 102,658 & 20,714 & 17,042 & 1,490 & 19,887 \\
\hline 2004 & 18,059 & 163,724 & 27,784 & 28,197 & 1,242 & 14,926 \\
\hline 2005 & 10,505 & 167,439 & 27,015 & 28,250 & 999 & 12,890 \\
\hline
\end{tabular}

Notes: A firm's ownership type is determined based on its registration. HMT stands for Hong Kong, Macau, or Taiwan.

Crucial for our analyses, the dataset includes data on the firm's payments of different kinds of taxes. We compute the ratio of a firm's actual payment of VAT to its value-added in the same year to construct its de facto VAT rate. Notice that the de facto VAT rates may differ substantially from the de jure rates for various reasons. First, different fiscal constraints faced by local governments may affect the tax collection effort and also the amount of rebates. Second, it is well known that the Chinese government uses VAT rebates to promote firms' exports. Despite the fact that the VAT rate for manufacturing firms is set at a uniform rate of $17 \%$, a firm's actual VAT payable is ${ }^{17}$

$$
\begin{aligned}
\text { Actual VAT }= & 17 \% \times(\text { Domestic sales }+ \text { Exports } \\
& - \text { Inputs }- \text { BIM })- \text { rebate rate } \\
& \times(\text { Exports }- \text { BIM }),
\end{aligned}
$$

where BIM stands for bonded (or tax-free) imported materials.

Table 1 reports the distribution of firms of different ownership types in the group that pays $0 \mathrm{VAT}$, and each quartile of the de facto VAT rates. Figure $2 \mathrm{a}$ and $\mathrm{b}$ illustrates the kernel density of the de facto VAT rates across all firms in the pooled sample. As the figures reveal, there is a large variation in the VAT rate across firms, and a significant fraction of firms actually had zero VAT. A reason is that the Chinese government has been offering tax rebates to exporting firms to promote firms' exports. In particular, export-processing firms, many of which are FIEs, can receive full rebates on VAT for imported inputs used for exports (Defever \& Riaño, 2017). To verify the hypothesis that the Chinese authorities favored FIEs in the collection of VAT, we will need to control for firms' export participation and intensity in the regressions. Importantly, the figures show that the distribution of the VAT rate is more leftward skewed toward 0 for FIEs than domestic firms, especially the private ones.

In addition to the detailed data on taxes, the dataset contains information on the value of equity owned by different types of investors, as well as a firm's registration type. This information allows us to examine the pattern of economic outcomes across firms with different ownership types, especially that between foreign and domestic firms. Although the dataset provides no information on the country of origin of a foreign firm, it does record the share of equity owned by ethnic Chinese investors from Hong Kong, Macau, or Taiwan. Therefore, we can categorize foreign firms into ethnic Chinese and non-Chinese foreign firms.

Moreover, among domestic enterprises, information on different ownership types - (1) state-owned enterprises (SOEs) (owned by either the local or the central government), (2) collective owners (e.g., township and village cooperatives, usually with ownership by local governments), (3) institutional investors, and (4) domestic private investors - 
Table 2 Ownership types by quartiles of the de facto VAT rates

\begin{tabular}{|c|c|c|c|c|c|c|c|}
\hline Numbers in \% & Foreign (non-HMT) & Foreign (HMT) & State & Domestic private & Collective & Mixed & No. of firms \\
\hline 0 VAT & 19.16 & 23.42 & 15.33 & 29.80 & 11.24 & 0.75 & 141,633 \\
\hline \multicolumn{8}{|l|}{ VAT percentiles } \\
\hline$(0,25]$ & 8.45 & 11.19 & 12.12 & 49.47 & 17.60 & 0.88 & 302,558 \\
\hline$(25,50]$ & 6.73 & 8.67 & 13.66 & 53.85 & 15.90 & 0.99 & 302,558 \\
\hline$(50,75]$ & 6.95 & 8.19 & 14.24 & 54.34 & 14.90 & 1.21 & 302,568 \\
\hline$(75,100]$ & 7.33 & 8.45 & 19.05 & 48.24 & 15.38 & 1.38 & 302,555 \\
\hline
\end{tabular}

Notes: A firm (in a given year) belongs to the VAT $(x, y]$ bracket if its de facto VAT rate is higher than $x \%$ of the firms paying the VAT and lower than or equal to $y \%$ of the firms paying the VAT.

A firm's ownership type is determined based on its registration.

HMT stands for Hong Kong, Macau, or Taiwan.

The percentages are calculated using the pooled sample over 1998-2005 (8 years).

allows us to examine whether foreign firms face a lower de facto VAT rate relative to domestic firms of various ownership types. The benchmark group in which we are most interested is at the lowest of the political pecking order - domestic private firms. In Table 2, we report the shares of different ownership types for each year in terms of the number of firms and value-added. The well-known privatization trend in China reveals that the market shares of SOE and collectively owned firms were declining over the sample period, whereas the market shares of domestic private and foreign firms were increasing to fill the gap over time.

Our empirical results depend largely on the presence of a sufficient number of foreign firms in the sample. In our cleaned sample, $19 \%$ of the observations are of foreign firms according to their registration types (compared to $17.5 \%$ of stateowned enterprises). If we consider firms with more than $25 \%$ foreign equity as foreign-owned, $15 \%$ of the sample firms are defined as foreign. (China's foreign investment law defines a firm as "foreignowned" if foreign ownership exceeds $25 \%$, in contrast to $10 \%$ threshold in OECD countries.)

We control for a host of firm characteristics in our regressions, such as a firm's gross output (constant prices), value-added (constant prices), employment, capital stock, export status, employment share, and value-added share in the provincesector aggregate a firm belongs to (see Data Appendix for the summary statistics). ${ }^{18} \mathrm{~A}$ firm's employment is measured by the total number of employees. Capital stock is measured as the net value of fixed assets, deflated by the provincespecific weighted average of separate cost indices for investments in construction and installation, and purchases of equipment and instruments, available in various issues of China's Statistical Yearbook (1999-2006).
To ensure that our empirical results are not driven by extreme outliers due to measurement errors, in our final sample we "winsorize" observations for which the dependent and the key independent variables are larger than the 99 percentile or smaller than the 1 percentile of the corresponding variables in the sample. The "winsorized" sample contains 1,384,250 observations (on average 173,031 firms per year). ${ }^{19}$ See Table 3 for the summary statistics of the key variables included in the regressions.

\section{Empirical Strategy}

To examine whether foreign enterprises on average face a lower VAT rate, we estimate the following firm-level empirical specification:

$$
\begin{aligned}
(\text { Actual VAT/VA })_{i j r t}= & \alpha+\beta f_{i t}+X_{i j r t} \gamma+\delta_{j}+\delta_{r}+\delta_{t} \\
& +\varepsilon_{i j r t} .
\end{aligned}
$$

The subscripts $i, j, r$, and $t$ stand for firm, sector, province, and year, respectively. The dependent variable, (Actual VAT/VA) $)_{i j r t}$, is the de facto valueadded tax rate, which is defined as the firm's selfreported actual payment of value-added taxes divided by its self-reported value-added in the same calendar year.

Our regressor of interest, $f_{i t}$, is an indicator variable, which equals 1 when firm $i$ 's registration type is a foreign firm in year $t$ (both wholly owned foreign firms and joint ventures) and 0 otherwise. The foreign-ownership hypothesis implies that $\beta<0$.

$X_{i j r t}$ contains a set of firm-level control variables, which includes the firm's export status, size, age, and contribution to local government revenue. In addition to the constant term $\alpha$, sector $\left(\delta_{j}\right)$, province $\left(\delta_{r}\right)$, and year $\left(\delta_{t}\right)$ fixed effects are always included. Sector and province fixed effects capture 
Table 3 Baseline results

\begin{tabular}{|c|c|c|c|c|c|c|c|}
\hline \multirow[t]{2}{*}{ Dependent variable } & \multicolumn{6}{|c|}{ VAT/VA } & \multirow{2}{*}{$\frac{I(\mathrm{VAT}>0)}{(7)}$} \\
\hline & (1) & $(2)$ & (3) & (4) & $(5)$ & (6) & \\
\hline Foreign dummy & $\begin{array}{l}-0.026^{\star * *} \\
(0.002)\end{array}$ & $\begin{array}{l}-0.026^{\star * *} \\
(0.002)\end{array}$ & $\begin{array}{l}-0.013^{* * *} \\
(0.003)\end{array}$ & $\begin{array}{l}-0.014^{\star * *} \\
(0.003)\end{array}$ & $\begin{array}{l}-0.017^{* * *} \\
(0.003)\end{array}$ & $\begin{array}{l}-0.016^{* * *} \\
(0.003)\end{array}$ & $\begin{array}{l}-0.687^{\star * *} \\
(0.027)\end{array}$ \\
\hline In(labor) & & $\begin{array}{l}0.003^{* * *} \\
(0.001)\end{array}$ & $\begin{array}{l}0.022^{* * *} \\
(0.002)\end{array}$ & $\begin{array}{l}0.022^{* * *} \\
(0.002)\end{array}$ & $\begin{array}{l}0.021^{* * *} \\
(0.002)\end{array}$ & $\begin{array}{l}0.022^{* * *} \\
(0.002)\end{array}$ & $\begin{array}{l}-0.006 \\
(0.010)\end{array}$ \\
\hline In(capital) & & $\begin{array}{l}0.000 \\
(0.000)\end{array}$ & $\begin{array}{l}0.008^{\star * *} \\
(0.001)\end{array}$ & $\begin{array}{l}0.008^{* * *} \\
(0.001)\end{array}$ & $\begin{array}{l}0.008^{* * *} \\
(0.001)\end{array}$ & $\begin{array}{l}0.008^{\star * *} \\
(0.001)\end{array}$ & $\begin{array}{l}-0.030^{\star * *} \\
(0.005)\end{array}$ \\
\hline In(age) & & $\begin{array}{l}0.006^{* * *} \\
(0.000)\end{array}$ & $\begin{array}{l}0.004^{* * *} \\
0.000\end{array}$ & $\begin{array}{l}0.005^{* * *} \\
0.000\end{array}$ & $\begin{array}{l}0.004^{* * *} \\
(0.000)\end{array}$ & $\begin{array}{l}0.004^{* * *} \\
(0.000)\end{array}$ & $\begin{array}{l}0.083^{* * *} \\
(0.007)\end{array}$ \\
\hline Exporter dummy & & & $\begin{array}{l}-0.015^{\star * *} \\
(0.002)\end{array}$ & 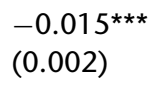 & & & $\begin{array}{l}-0.417^{\star \star *} \\
(0.021)\end{array}$ \\
\hline Exports/sales & & & & & $\begin{array}{l}-0.034^{* * *} \\
(0.007)\end{array}$ & $\begin{array}{l}-0.140^{* * *} \\
(0.023)\end{array}$ & \\
\hline$($ Exports/sales)^2 & & & & & & $\begin{array}{l}0.116^{\star * *} \\
(0.024)\end{array}$ & \\
\hline SOE dummy & & & & $\begin{array}{l}-0.013^{\star \star *} \\
(0.002)\end{array}$ & $\begin{array}{l}-0.013^{* * *} \\
(0.002)\end{array}$ & $\begin{array}{l}-0.013^{\star \star *} \\
(0.002)\end{array}$ & $\begin{array}{l}-0.218^{\star \star *} \\
(0.022)\end{array}$ \\
\hline Collective firm dummy & & & & $\begin{array}{l}-0.002^{*} \\
(0.001)\end{array}$ & $\begin{array}{l}-0.002^{*} \\
(0.001)\end{array}$ & $\begin{array}{l}-0.002 \\
(0.001)\end{array}$ & $\begin{array}{l}-0.127^{\star \star \star} \\
(0.018)\end{array}$ \\
\hline In(value-added) & & & & $\begin{array}{l}-0.032^{\star \star \star} \\
(0.001)\end{array}$ & $\begin{array}{l}-0.032^{\star * *} \\
(0.001)\end{array}$ & $\begin{array}{l}-0.032^{\star * *} \\
(0.001)\end{array}$ & $\begin{array}{l}0.172^{\star * *} \\
(0.006)\end{array}$ \\
\hline Emp share in province-sector & & & & $\begin{array}{l}0.010 \\
(0.008)\end{array}$ & $\begin{array}{l}0.011 \\
(0.008)\end{array}$ & $\begin{array}{l}0.010 \\
(0.008)\end{array}$ & $\begin{array}{l}0.152^{\star * *} \\
(0.050)\end{array}$ \\
\hline VA share in province-sector & & & & $\begin{array}{l}0.000 \\
(0.006)\end{array}$ & $\begin{array}{l}0.001 \\
(0.006)\end{array}$ & $\begin{array}{l}0.001 \\
(0.006)\end{array}$ & $\begin{array}{l}-0.115^{\star * *} \\
(0.041)\end{array}$ \\
\hline Sector FEs (175) & Yes & Yes & Yes & Yes & Yes & Yes & Yes \\
\hline Province FEs (30) & Yes & Yes & Yes & Yes & Yes & Yes & Yes \\
\hline Year fixed (7) & Yes & Yes & Yes & Yes & Yes & Yes & Yes \\
\hline $\begin{array}{l}\text { Num. obs. } \\
R^{2}\end{array}$ & $\begin{array}{l}1,335,397 \\
0.08\end{array}$ & $\begin{array}{l}1,310,227 \\
0.08\end{array}$ & $\begin{array}{l}1,310,227 \\
0.09\end{array}$ & $\begin{array}{l}1,256,155 \\
0.14\end{array}$ & $\begin{array}{l}1252087 \\
0.14\end{array}$ & $\begin{array}{l}1,252,087 \\
0.14\end{array}$ & $\begin{array}{l}1,256,155 \\
0.18\end{array}$ \\
\hline
\end{tabular}

Notes This table reports the results of estimating equation (1) in the text. The dependent variable is the de facto VAT rate in columns (1) through (6), which equals the self-reported VAT payment divided by the self-reported firm value-added. Column (4) includes state-owned enterprise (SOE) and collectively owned firm dummies, so the negative coefficient on the foreign dummy can be interpreted as the partial effects of being a foreign firm on the de facto VAT rate relative to a domestic private firm (the excluded group of firms). The last column reports the estimation results using a Probit model, with the dependent variable equal to 1 if the firm pays any VAT.

All specifications include a constant, 175 sectors, 30 provinces, and 7-year fixed effects.

Standard errors, clustered at the province-sector level, are reported in parentheses.

$\star * *, * *$, and * denote 1,5 , and $10 \%$ significance levels, respectively.

Pseudo- $R^{2}$ is reported in column (7).

the variation in the de facto VAT rates across sectors (176 three-digit sectors) and provinces (twentyeight provinces plus three municipalities - Beijing, Shanghai, and Tianjin) due to, for example, different enforcement difficulties and incentives for tax collection across sectors and provinces. Year fixed effects capture any possible regulatory or execution changes in VAT adjustments that either the central or local governments make in a given year. $\varepsilon_{\mathrm{ijrt}}$ is an error term, which is assumed to be uncorrelated with the regressors, and i.i.d. across time.

We estimate specification (1) using OLS, with standard errors clustered at the province-sector level to take into account the correlation between observations within the same sector. ${ }^{20}$

\section{EMPIRICAL EVIDENCE OF FOREIGN- OWNERSHIP BIASES}

\section{Baseline Results}

Table 3 reports the baseline empirical results of the article. In column (1), using a firm's registration type to classify firm ownership type, we regress a firm's de facto value-added tax rate (VAT rate) on its foreign firm dummy, together with sector (three- 
digit, 176 sectors), province (31 provinces or province-level municipal cities), and year (8 years) fixed effects. We find that within a province-sectoryear cell, foreign firms face on average a 2.6 percentage-point lower VAT rate than domestic firms (which include private, collectively owned, and state-owned firms). This finding is statistically significant at the $1 \%$ level.

To circumvent the effects of firms' size and age, which are possibly associated with a greater bargaining power and thus lower tax rates, in column (2) we add the natural logarithms of a firm's employment, capital stock, and age as regressors. In contrast with the bargaining theory, we find that larger (in terms of employment) and older firms have a higher de facto VAT rate. ${ }^{21}$

To promote export-led growth, the Chinese government has granted tax incentives to exporting firms. A firm receives rebates on VAT paid for the exported portion of its value-added (Ferrantino, Liu, \& Wang, 2012; Chandra \& Long, 2013; Defever \& Riaño, 2017). VAT was even fully exempted on imported materials for export processing. Given that FIEs are on average more export-oriented than domestic firms in China, in column (3) we add an indicator for whether a firm is an exporter to separate the effect of export participation on a firm's VAT, due to export rebates, from the foreignownership effects. We find that indeed exporters do enjoy an average 1.5 percentage-point lower effective VAT rate than non-exporters.

In column (4), a firm's log value-added is included to further control for the firm-size effect on VAT. We also control for a firm's employment share and value-added share, respectively, in the province-sector total to account for its contribution to the local government's revenue. In addition, it is widely perceived that SOEs and collectively owned firms face soft budget constraints. Tax collection from these enterprises may be more lax than that from private firms. Thus, we also include dummies for both SOEs and collectively owned enterprises, so that we can gauge the effects of foreign ownership on the de facto VAT rate relative only to domestic private firms (the excluded group). We find that the coefficients on the dummies of all three ownership types are negative and significant (1\% level for foreign and state dummies, $10 \%$ level for collective dummies). In other words, FIEs, SOEs, and collectively owned firms (e.g., township and village cooperatives) all face lower de facto VAT rates compared with domestic private firms. Importantly, the magnitude of the coefficients on the foreign dummy and SOE dummy is not statistically different, implying that FIEs receive VAT discounts that are indistinguishable from those enjoyed by SOEs. This is a significant finding. It suggests the possibility that FIEs, at least in terms of VAT policies, enjoyed similar levels of policy treatments as those firms perched at the very top of the political pecking order - the SOEs. In sum, after controlling for firm size, age, exporter status, and contribution to government revenue, we still find that FIEs systematically face a lower de facto VAT rate.

One may argue that simply controlling for a firm's exporter status in column (3) is not sufficient, as the VAT payable depends on the value of exports and imports for further processing (Ferrantino, Liu, \& Wang, 2012; Chandra \& Long, 2013; Defever \& Riaño, 2017). To address this concern, instead of controlling for a firm's exporter dummy, we control for the firm's ratio of exports to total sales in column (5), and additionally the squared term of such ratio in column (6). We find that the more a firm exports, the lower the effective VAT rate, supporting previous findings that many Chinese firms avoid paying VAT at the full official rate by exporting some of the output (e.g., Gourdon, Hering, Monjon, \& Poncet, 2014).

Figure $2 \mathrm{a}$ and $\mathrm{b}$ shows the predominance of FIEs paying no VAT. This observation warrants an empirical examination of whether, compared to domestic firms, FIEs are more likely to be exempted from the VAT altogether. We take the specification of (4) but replace the dependent variable by an indicator function that equals 1 if the firm reports paying a positive VAT in the corresponding year, and 0 if it reports paying no VAT. The results in column (7) suggest that foreign ownership significantly increases the likelihood of a VAT exemption. The marginal impact is economically important. Evaluating at the means of all independent variables, the point estimate on the foreign dummy implies that being a FIE decreases the probability of paying the VAT by 13.54 percentage points. Note also that compared with domestic private firms, both SOEs and collectively owned enterprises (partly controlled by local governments) are also more likely to be exempt from the VAT.

\section{Different Foreign-Ownership Types}

In Table 4, we examine whether the organizational forms and countries of origin of the FIEs are related to the degree of policy biases. We first break down 
Table 4 Different foreign-ownership types

Dependent Variable $=$ VAT/VA

(1)

$$
\begin{aligned}
& -0.010^{* * *} \\
& (0.004)
\end{aligned}
$$

For. (HMT)

For. Wholly owned (WO)

$-0.017^{* * *}$

(0.002)

For. Joint-venture (JV)

For. (non-HMT; WO)

For. (non-HMT; JV)

For. (HMT; WO)

For. (HMT; JV)

SOE dummy

Collective dummy

Controls

Fixed effects

\begin{tabular}{llll}
\hline Num. obs. & $1,256,155$ & $1,256,155$ & $1,256,155$ \\
$R^{2}$ & 0.14 & 0.14 & 0.14 \\
\hline
\end{tabular}

This table examines whether different types of foreign firms are associated with different de facto VAT rates. The dependent variable is the de facto VAT rate, which equals the self-reported VAT payment divided by the self-reported firm value-added. The types of foreign firms investigated include (1) wholly owned versus joint ventures; (2) foreign firms invested by ethnic Chinese investors from Hong Kong, Macau, or Taiwan versus non-Chinese foreign firms.

Notes: All specifications include a constant, 175 sectors, 30 provinces, and 7-year fixed effects, and control for firm-level characteristics: In(labor), In(capital), In(age), In(value-added), exporter dummy, employment share, and value-added share.

Standard errors, clustered at the province-sector level, are reported in parentheses.

$* * *, * *$, and ${ }^{*}$ denote 1,5 , and $10 \%$ significance levels, respectively.

the foreign dummy into one for FIEs owned by non-Chinese investors, and one for FIEs owned by ethnic Chinese investors from Hong Kong, Macau, or Taiwan (HMT). Controlling for firm-level characteristics as in column (5) of Table 3, we find negative and statistically significant coefficients on both foreign dummies, as shown in column (1). While the coefficient on the HMT dummy is larger than that on the non-HMT dummy, it is not statistically different.

We then decompose the foreign dummy based on organizational structure and examine whether wholly owned (WO) FIEs are treated more favorably than joint ventures (JV). We find negative coefficients on both the WO and JV dummies, but only the former is statistically significant (see column (2)). In particular, relative to domestic private firms, wholly owned FIEs face a de facto VAT rate 3.4 percentage points lower than that of domestic private firms, whereas there is no significant difference between JVs and domestic private firms.

Finally, we examine four different foreign firm ownership types simultaneously by including all four foreign firm dummies as regressors (i.e., along the Chinese/non-Chinese dimension and along the $\mathrm{WO} / \mathrm{JV}$ dimension). Column (3) shows negative coefficients on all foreign dummies, with the two for wholly owned FIEs being statistically significant, independent of the ethnic origin of FIEs. These results show that foreign firms are not only favored, but the degree of "foreignness," captured by the extent of control rights and the ownership structure, also matters.

\section{Alternative Definitions of Foreign Ownership}

So far we have been using a firm's registration type to classify its ownership. A potential criticism is that registration types may not represent the 
Table 5 Foreign equity share

Dependent variable $=$ VAT/VA

\begin{tabular}{|c|c|c|c|c|}
\hline & (1) & $(2)$ & (3) & (4) \\
\hline Foreign-ownership definition & $25 \%$ Equity share & $50 \%$ Equity share & N.A. & N.A. \\
\hline Foreign dummy & $\begin{array}{l}-0.013^{\star \star *} \\
(0.001)\end{array}$ & $\begin{array}{l}-0.021^{\star * *} \\
(0.001)\end{array}$ & & \\
\hline Foreign equity share & & & $\begin{array}{l}-0.028^{\star * \star} \\
(0.002)\end{array}$ & \\
\hline Non-Chinese foreign equity shr. & & & & $\begin{array}{l}-0.022^{\star * *} \\
(0.002)\end{array}$ \\
\hline Ethnic Chinese foreign equity shr. & & & & $\begin{array}{l}-0.033^{\star * \star} \\
(0.002)\end{array}$ \\
\hline Controls \& fixed effects & Yes & Yes & Yes & Yes \\
\hline Num. obs. & $1,256,155$ & $1,256,155$ & $1,246,124$ & $1,246,124$ \\
\hline$R^{2}$ & 0.14 & 0.14 & 0.14 & 0.14 \\
\hline
\end{tabular}

This table examines whether the degree of "foreignness" of a firm is associated with a different de facto VAT rate. The dependent variable is the de facto VAT rate, which equals the self-reported VAT payment divided by the self-reported firm value-added. In particular, the degree is measured by the share of foreign equity. A firm is considered foreign if it has at least $x \%$ foreign equity share. Two different cutoffs, $x=25$ and $x=50$, are used to define foreign ownership. A continuous relationship between the foreign equity share and the de facto VAT rate is examined in column (4).

Notes: All specifications include a constant, 175 sectors, 30 provinces, and 7-year fixed effects, and firm-level controls: In(labor), In(capital), In(age), In(value-added), exporter dummy, SOE dummy, collective dummy, employment share, and value-added share (i.e., the specification of column (5) in Table 3).

Standard errors, clustered at the province-sector level, are reported in parentheses.

$* * *, * *$, and * denote 1,5 , and $10 \%$ significance levels, respectively.

Ethnic Chinese firms are foreign firms with registered owners from Hong Kong, Macau, or Taiwan. Non-Chinese firms are all other foreign firms.

underlying ownership and control rights of the firms. Because China's policies and laws may not be grounded precisely on how a firm is registered, we consider other dimensions of a firm's "foreignness" in Table 5. In column (1), we repeat the analogous regression analysis (column (5) in Table 3 ) with the foreign dummy equal to 1 if a firm has more than $25 \%$ (inclusive) foreign equity share, and 0 otherwise. We continue to find a negative coefficient on the foreign dummy. In particular, the point estimate on the foreign dummy constructed based on the $25 \%$ cutoff shows that FIEs on average face a de facto VAT rate 1.3 percentage points lower than that of domestic private firms. In column (2), we run the same regression, but now raise the bar for foreign ownership - a firm is considered foreign if its foreign equity share exceeds $50 \%$ (inclusive). The coefficient on the foreign dummy now rises to (negative) $2.1 \%$, and is statistically different from the one on the $25 \%$ cutoff foreign dummy in column (1).

These results warrant an investigation of a relationship between foreign equity share and VAT rates across firms. In column (3), a firm's de facto VAT rate is regressed on its foreign equity share. The coefficient on the share of foreign equity is negative and statistically significant (at the 1\% level). Under the assumption that the relationship between a firm's foreign equity share and its VAT rate is linear, the point estimate in column (3) suggests that a $10 \%$ increase in a firm's foreign equity share is associated with a remarkable 0.28 percentage point decrease in its de facto VAT rate.

One of the complications in studies of FDI in China is the presence of "round-trip" capital. Round-trip capital refers to Chinese firms acquiring a foreign domicile and using that foreign domicile to invest in China. Thus, one concern about our finding is that the benefits of foreign-ownership bias accrue to the Chinese ultimate owners of these FIEs rather than to the genuinely foreign ultimate owners.

This concern can be addressed in two ways. One is to note that the population of ultimate owners of domestic firms is all Chinese (by definition), whereas the population of ultimate owners of FIEs is only partially Chinese. (How partial is the Chinese ownership will depend on the extent of round-trip FDI.) Thus even in the presence of round-trip FDI, our findings are still supportive of the foreign-ownership hypothesis. The VAT liabilities, all else being equal, are lower for a population of ultimate owners that is partially Chinese than for a population of ultimate owners that is completely Chinese. The existence of round-trip FDI does not invalidate our conclusion at all. 
Table 6 Different subsamples of firms

\begin{tabular}{|c|c|c|c|c|c|c|c|}
\hline Dependent variable $=$ VAT/VA & & & & & & & \\
\hline & (1) & $(2)$ & (3) & (4) & (5) & (6) & (7) \\
\hline Sample & $\begin{array}{l}\text { Small } \\
\text { (by VA) }\end{array}$ & $\begin{array}{l}\text { Large } \\
\text { (by VA) }\end{array}$ & $\begin{array}{l}\text { Small } \\
\text { (by emp) }\end{array}$ & $\begin{array}{l}\text { Large } \\
\text { (by emp) }\end{array}$ & Non-SEZ & SEZ & $\begin{array}{l}\text { Private } \\
\text { only }\end{array}$ \\
\hline Foreign dummy & $\begin{array}{l}-0.023^{* * *} \\
(0.002)\end{array}$ & $\begin{array}{l}-0.008^{* * *} \\
(0.001)\end{array}$ & $\begin{array}{l}-0.001 \\
(0.001)\end{array}$ & $\begin{array}{l}-0.022^{* * *} \\
(0.002)\end{array}$ & $\begin{array}{l}-0.011^{* * *} \\
(0.002)\end{array}$ & $\begin{array}{l}-0.018^{* * *} \\
(0.002)\end{array}$ & $\begin{array}{l}-0.011^{* * *} \\
(0.001)\end{array}$ \\
\hline Controls \& fixed effects & Yes & Yes & Yes & Yes & Yes & Yes & Yes \\
\hline Num. obs. & 607,876 & 648,279 & 622,414 & 633,741 & 954,348 & 301,807 & 901,970 \\
\hline$R^{2}$ & 0.12 & 0.15 & 0.14 & 0.16 & 0.15 & 0.14 & 0.14 \\
\hline
\end{tabular}

This table examines the relationship between the de facto VAT rates and foreign ownership using different samples: (i) large and small firms in columns (1) through (4); (ii) firms in the special economic zones (SEZs) versus firms outside the SEZs in column (5) and (6); (iii) excluding all state-owned and collectively owned non-private firms in column (7). The dependent variable is the de facto VAT rate, which equals the self-reported VAT payment divided by the self-reported firm value-added.

Notes: All specifications include a constant, 175 sectors, 30 provinces, and 7-year fixed effects, and firm-level controls: In(labor), In(capital), In(age), In(value-added), exporter dummy, SOE dummy, collective dummy, employment share, and value-added share. (i.e., the specification of column (5) in Table 3).

Standard errors, clustered at the province-sector level, are reported in parentheses.

$* * *, * *$, and * denote 1,5 , and $10 \%$ significance levels, respectively.

Because there is no information on round-trip FDI, we cannot directly estimate the VAT liabilities on round-trip firms but one class of FIEs can serve as a proxy of round-trip firms. These are ethnically Chinese firms based in Hong Kong, Macau, and Taiwan (HMT). Most of the round-trip FDI goes through overseas Chinese territories such as Hong Kong and Macau. We examine different effects of foreign ownership from ethnic Chinese and nonChinese foreign investors, respectively (column (4)). Although both types of foreign firms are found to be favored, we find that increasing the ethnic Chinese foreign equity share results in a larger VAT discount, although the VAT discount on nonethnic Chinese firms remains statistically significant. It is likely, although not certain, that much of the round-trip FDI effect should show up in the coefficient of the ethnically Chinese FIEs.

In sum, regardless of the definitions of foreign firms, we find evidence of foreign-ownership biases. We also find that the degree of "foreignness," captured by either a higher foreign equity share or a wholly owned ownership structure, is positively related to the de facto VAT discount.

\section{Heterogeneous Effects across Different Subsamples of Firms}

To test the robustness, we repeat the baseline analysis (column (5) in Table 3) using different subsamples of firms. First, we divide the sample into large-firm and small-firm samples. The theoretical predictions are non-trivial. On the one hand, larger firms are more able to bargain for lower VAT rates. On the other hand, both central and regional governments have stronger incentives to enforce tax regulations for larger firms since they are an important source of government tax revenue. In Table 5, we repeat our baseline analysis on the sample of firms with value-added above the median (large firms) in the corresponding year in column (1), and another one with firms having value-added below the median (small firms) in column (2). We find a negative and significant coefficient on the foreign dummy for both samples, but the foreignownership bias appears to be significantly more pronounced among the small firms (coefficient $=-0.023$ ) than the large firms (coefficient $=-0.008$ ). These findings imply that foreign-ownership biases arise to a large extent from policies against smaller domestic private firms. These results are consistent with the "bargaining" hypothesis that states that the Chinese government is reluctant to implement and execute policies against large domestic firms (Table 6).

In columns (3) and (4), we use firm employment as the criteria to define the large-firm and smallfirm samples. In contrast to the results in columns (1) and (2), we find a foreign bias only among the large firms. This seemingly contradicts the results on value-added but the finding could also suggest the possibility that Chinese tax policies are biased against employment in favor of value-added of firms. This issue requires further investigations than the scope of the current article allows. 
Next, we separate firms operating in the Special Economic Zones (SEZ) from those outside the zones (non-SEZ). Initially, the SEZs were regions set up by the Chinese central government to experiment with pro-market economic policies. Unlike other areas in China, governments in the SEZs have been permitted, and sometimes encouraged, to implement policies to promote integration in international markets. Among the SEZs, Shenzhen in Guangdong province was the first to receive FDI after a series of economic reforms that began in 1978. Given their special authority, since the early 1980s the SEZs have implemented more pro-foreign policies than other regions to attract FDI. As such, a substantial number of FIEs were located in the SEZs to take advantage of policies that promote exports and FDI. In columns (5) and (6), we examine whether foreign-ownership biases are only found in the SEZs. We find foreign-ownership biases in both the SEZs and the non-SEZs, but the magnitude of the bias is twice as large in the SEZs.

Finally, in column (7), we exclude both SOEs and collectively owned firms from the sample and focus entirely on the bias against domestic private firms. The coefficient on the foreign dummy remains negative and significant.

\section{TOWARD AN UNDERSTANDING OF FOREIGN-OWNERSHIP BIASES}

After empirically identifying the existence of foreign-ownership biases, we now examine the variation in the degree of the biases across sectors and provinces to formulate a tentative conjecture on the determinants of the biases.

\section{Provincial Determinants}

According to Grossman and Helpman's politicaleconomic framework (1994), a government chooses trade policy instruments to maximize a weighted political support function over consumer welfare and political contributions. Branstetter and Feenstra (2003) structurally estimate the regional government objective function based on the Grossman-Helpman framework using provincelevel trade and FDI data from China. They find that on average provincial governments in China attach a significantly higher weight to SOE sales relative to consumer welfare.

We adopt a similar theoretical framework and consider that a provincial government adopts economic policies to maximize its objective, which is a weighted average of the sales of domestic firms,
FIEs, and SOEs, as well as consumer welfare. ${ }^{22}$ Intuitively, the local government should attach a higher weight to the output of SOEs when their share in the local economy is larger. As such, a weaker foreign-ownership bias is expected in provinces where SOEs account for a larger share of the economy.

Similarly, a higher weight on domestic private firms' output can be found in provinces where local government officials have more vested interests in the private sector. An alternative hypothesis based on the existence of the political pecking order of firms in China would imply that local governments tend to implement and execute policies to curb the rising economic and political power of the private sector. Thus, a negative relationship between the market share of domestic private firms and the foreign-ownership bias is expected.

Moreover, if a larger share of FIE output is exported, the FIEs' competitive pressure on the domestic sector, particularly the SOEs, is mitigated. A stronger foreign-ownership bias is then expected in more export-oriented provinces.

Therefore, we explore the variations across provinces to examine the following hypothesis:

Hypothesis 1: The foreign-ownership biases, reflected in the de facto VAT rate gap between domestic private firms and FIEs, are larger in provinces with (1) a smaller SOE market share, (2) a larger domestic private market share, and (3) a larger export share.

To empirically examine Hypothesis 1, we include interaction terms between the value-added shares of different ownership types in the province and the foreign dummy, in addition to the stand-alone foreign dummy. The hypothesis predicts that the coefficient on the interaction with the SOE valueadded share is positive, whereas the coefficient on the interaction with the domestic private valueadded share is negative. Table 7 reports the estimation results. In column (1), we find a positive and significant coefficient on the interaction term between the SOEs' value-added share and the foreign dummy (significant at the 1\% level), whereas we continue to find a negative coefficient on the stand-alone foreign dummy. We also find a positive and marginally significant coefficient (at the $10 \%$ level) on the SOEs' value-added share variable. These results support Hypothesis 1 regarding the relationship between the SOE prominence in the province and the foreign-ownership biases. 
Table 7 Interaction with value-added shares of different ownership types

\begin{tabular}{|c|c|c|c|c|c|c|}
\hline \multirow{2}{*}{$\begin{array}{l}\text { Dependent variable }=\text { VAT/VA } \\
\text { Year provincial characteristics } \\
\text { taken } \\
\text { Provincial characteristics }\end{array}$} & \multicolumn{3}{|c|}{ Current year } & \multicolumn{3}{|c|}{ Two years ago } \\
\hline & $\begin{array}{l}\text { SOE mkt. } \\
\text { share } \\
(1)\end{array}$ & $\begin{array}{l}\text { Private firm mkt. } \\
\text { share } \\
(2)\end{array}$ & $\begin{array}{l}\text { Export } \\
\text { orient. } \\
\text { (3) }\end{array}$ & $\begin{array}{l}\text { SOE mkt. } \\
\text { share } \\
(4)\end{array}$ & $\begin{array}{l}\text { Private firm mkt. } \\
\text { share } \\
(5)\end{array}$ & $\begin{array}{l}\text { Export } \\
\text { orient. } \\
(6)\end{array}$ \\
\hline Foreign dummy & $\begin{array}{l}-0.038^{* * *} \\
(0.002)\end{array}$ & $\begin{array}{l}-0.022^{* * *} \\
(0.004)\end{array}$ & $\begin{array}{l}0.027^{* * *} \\
(0.002)\end{array}$ & $\begin{array}{l}-0.038^{* * *} \\
(0.002)\end{array}$ & $\begin{array}{l}-0.006^{*} \\
(0.004)\end{array}$ & $\begin{array}{l}0.027^{* * *} \\
(0.003)\end{array}$ \\
\hline SOE/total VA $\times$ foreign & $\begin{array}{l}0.126^{* * *} \\
(0.008)\end{array}$ & & & $\begin{array}{l}0.070^{* * *} \\
(0.005)\end{array}$ & & \\
\hline SOE/total VA & $\begin{array}{l}0.028^{*} \\
(0.009)\end{array}$ & & & $\begin{array}{l}-0.026^{\star \star *} \\
(0.004)\end{array}$ & & \\
\hline Private/total VA $\times$ foreign & & $\begin{array}{l}0.019 * * \\
(0.009)\end{array}$ & & & $\begin{array}{l}-0.022^{\star * *} \\
(0.007)\end{array}$ & \\
\hline Private/total VA & & $\begin{array}{l}-0.007 \\
(0.008)\end{array}$ & & & $\begin{array}{l}0.019^{* * *} \\
(0.004)\end{array}$ & \\
\hline Export/total sales $\times$ foreign & & & $\begin{array}{l}-0.169^{\star * *} \\
(0.009)\end{array}$ & & & $\begin{array}{l}-0.164^{\star \star \star} \\
(0.010)\end{array}$ \\
\hline Export/total sales & & & $\begin{array}{l}-0.014 \\
(0.017)\end{array}$ & & & $\begin{array}{l}0.008 \\
(0.006)\end{array}$ \\
\hline Controls \& fixed effects & Yes & Yes & Yes & Yes & Yes & Yes \\
\hline Num. obs. & $1,256,155$ & $1,256,155$ & $1,256,155$ & $1,006,683$ & $1,006,683$ & $1,006,683$ \\
\hline$R^{2}$ & 0.14 & 0.14 & 0.14 & 0.15 & 0.14 & 0.15 \\
\hline
\end{tabular}

This table investigates how the shares of value-added (VA) by different ownership types in the province affect the impact of foreign ownership on the de facto VAT for foreign firms. The dependent variable is the de facto VAT rate, which equals the self-reported VAT payment divided by the self-reported firm value-added. The province-level variables examined include (1) SOE value-added (VA) shares; (2) domestic private firm VA shares; and (3) export shares in total sales. The variables lagged by 2 years are used in columns (4) through (6) to circumvent some, but not all, potential endogeneity problems.

Notes: All specifications include a constant, 175 sectors, 30 provinces, and 7-year fixed effects, and firm-level controls: In(labor), In(capital), In(age), In(value-added), exporter dummy, SOE dummy, collective dummy, and SOE and collective dummies interacted with the provincial characteristics, respectively, employment share and value-added share (i.e., the specification of column (5) in Table $3+$ the interaction terms). Standard errors, clustered at the province-sector level, are reported in parentheses.

$* * *, * *$, and ${ }^{*}$ denote 1,5 , and $10 \%$ significance levels, respectively.

This cross-province impact is economically significant. Consider two provinces, with one having $25 \%$ of GDP contributed by SOEs (e.g., Fujian in 2002) and the other having a 50\% SOE value-added share (e.g., Hubei in 2002). The foreign-ownership bias, measured by the difference in the de facto VAT discount, is about $3 \%$ smaller in the latter province. $^{23}$

Next, we examine the cross-province relationship between the foreign-ownership biases and the value-added share by domestic private firms. We continue to find a negative coefficient on the foreign dummy, while we find a positive and significant (at the 5\% level) coefficient on the interaction term. This result is inconsistent with the hypothesis. It says, in contrast to the hypothesis, that a higher private-sector market share is associated with a weaker foreign-ownership bias.

In column (3), we examine whether FIEs are more favored in provinces where a larger share of output is exported. We find negative and significant coefficients on both the foreign value-added share and its interaction with the foreign dummy, implying that foreign firms are more favored in more exportoriented provinces. It is worth noting that the stand-alone foreign dummy has a positive coefficient. This implies that in provinces that do not export enough, a foreign-ownership bias does not exist. In fact, Figure $3 \mathrm{~b}$ already shows that foreignownership biases do not exist in four out of the thirty-one provinces. The estimates of the regression show that if more than $16 \%$ of sales are exported, there will be a foreign-ownership bias in the province. A back-of-the-envelope calculation shows that FIEs were favored by the government at the expense of domestic private firms in the ten most export-oriented provinces (out of the thirtyone provinces) in 2005.

If a higher foreign firm value-added share in a province is simply a result of policies favoring FIEs, 
Table 8 Interaction with sectoral characteristics

\begin{tabular}{|c|c|c|c|c|}
\hline $\begin{array}{l}\text { Dependent variable = VAT/VA } \\
\text { Sectoral characteristics }\end{array}$ & $\begin{array}{l}(1) \\
\text { Skill-intensive (1) }\end{array}$ & $\begin{array}{l}(2) \\
\text { Skill-intensive (2) }\end{array}$ & $\begin{array}{l}\text { (3) } \\
\text { Capital-intensive }\end{array}$ & $\begin{array}{l}\text { (4) } \\
\text { R\&D-intensive }\end{array}$ \\
\hline Foreign & $\begin{array}{l}-0.038^{\star * *} \\
(0.003)\end{array}$ & $\begin{array}{l}-0.066^{\star * *} \\
(0.005)\end{array}$ & $\begin{array}{l}-0.038^{* \star *} \\
(0.002)\end{array}$ & $\begin{array}{l}-0.014^{\star \star *} \\
(0.002)\end{array}$ \\
\hline College grad/worker $\times$ foreign & $\begin{array}{l}0.182^{* * *} \\
(0.018)\end{array}$ & & & \\
\hline High-school grad/worker $\times$ foreign & & $\begin{array}{l}0.121^{\star * *} \\
(0.010)\end{array}$ & & \\
\hline Capital/output $\times$ foreign & & & $\begin{array}{l}0.101^{* * *} \\
(0.009)\end{array}$ & \\
\hline$R \& D$ intensity $\times$ foreign & & & & $\begin{array}{l}0.042 \\
(0.134)\end{array}$ \\
\hline Controls \& fixed effects & Yes & Yes & Yes & Yes \\
\hline Num. obs. & $1,256,155$ & $1,256,155$ & $1,256,155$ & $1,251,540$ \\
\hline$R^{2}$ & 0.14 & 0.14 & 0.14 & 0.14 \\
\hline
\end{tabular}

This table investigates how factor intensities of the sector affect the impact of foreign ownership on the de facto VAT rate for foreign firms. The dependent variable is the de facto VAT rate, which equals the self-reported VAT payment divided by the self-reported firm value-added.

Notes: All specifications include a constant, 175 sectors, 30 provinces, and 7-year fixed effects, and firm-level controls: In(labor), In(capital), In(age), In(value-added), exporter dummy, SOE dummy, collective dummy, and collective dummies interacted with the sectoral characteristics, respectively, employment share and value-added share (i.e., the specification of column (5) in Table $3+$ the interaction terms).

Standard errors, clustered at the province-sector level, are reported in parentheses.

${ }^{* * *},{ }^{* *}$, and ${ }^{*}$ denote 1,5 , and $10 \%$ significance levels, respectively.

one can argue that the results in columns (1) through (3) are biased due to reverse causality, e.g., a higher SOE market share is a result of less favorable tax treatment for FIEs. In an attempt to circumvent some of this problem, we use two-year lagged shares of different ownership types instead of the contemporaneous shares in columns (4) through (6). Interestingly, the coefficient on the interaction term with the market share of domestic private firms now turns negative and remains statistically significant (column 5), supporting Hypothesis 1 and the argument about the existence of a political pecking order of firms in China. Other results based on these lagged interaction terms are largely consistent with the results in columns (1) and (3). A more complete solution to the reverse causality problem, of course, requires the use of an instrument for shares of different ownership types.

The results that the SOE-dominated provinces had weaker foreign-ownership biases, whereas the private-dominated provinces had stronger foreignownership biases, have important implications. It is well known that SOEs are less efficient than domestic private firms in China (Dollar \& Wei, 2007; Hsieh \& Klenow, 2009). These results thus reject the argument that pro-foreign policies are in place to promote economic growth. Rather, they seem to arise mainly from political concerns to protect the SOEs.

\section{Sectoral Determinants}

In this section, we explore the variation across sectors to uncover whether the pro-foreign policies are based on efficiency grounds. One can argue the revealed foreign-ownership biases in China were simply an outcome of optimal policies aiming to attract foreign technology, capital, and knowhow. If that is the case, we should expect to find stronger biases in capital-intensive, skill-intensive, and R\&D-intensive sectors, where FDI has the most to bring to the host economy.

To verify this claim, we add interaction terms between the firm's foreign dummy and proxies for skill or capital intensities of the sector as regressors. If a pro-foreign execution of policies and regulations is meant to maximize economic growth, we should observe a negative coefficient on these interaction terms.

In Table 8, we find empirical evidence rejecting the "efficiency" argument. In column (1), we find a significantly positive coefficient on the interaction term between the foreign dummy and the ratio of college-educated workers to total employment at the industry level (four-digit), whereas we continue to find a negative coefficient on the foreign dummy. These results suggest a weaker foreignownership bias in skill-intensive sectors, rejecting the hypothesis that pro-foreign policies are growthenhancing. 
One may argue that using college-educated workers for a developing country like China is a rather restrictive measure of skill intensity. In column (2), we instead use the ratio of high-school graduate workers to total employment as a proxy for the skill intensity of the sector. We continue to find results confirming the findings in column (1).

Adding an interaction between the foreign dummy and the capital intensity of the sector (measured by the ratio of the real value of fixed capital to output) presents a consistent result. The positive coefficient on the interaction term in column (3) rejects the argument that pro-foreign tax policies aim to attract foreign machinery, equipment, or the embedded technology. Finally, we add an interaction term with the R\&D intensity of the sector in column (4), and find a positive estimate. The totality of evidence based on these exercises suggests that the foreign-ownership biases that we have documented here are unlikely to be growth improving.

To conclude, we find that China's ownershipbiased execution of laws and policies to be unlikely to promote growth. Together with the results from the regressions that include province-level interaction terms as regressors, the policy biases appear to be most likely due to political motives. This suggestive finding points to potential future research that can help us understand the larger political economy contexts and sources of these foreign-ownership biases. However, this is beyond the current scope of our article.

\section{CONCLUSIONS}

This article presents empirical evidence to show that foreign firms enjoy a lower de facto VAT rate on average than domestic private and state-owned enterprises in China, despite a statutorily uniform VAT rate for all types of firms. The findings are robust to the inclusion of a battery of firm-level controls and fixed effects, as well as different definitions of foreign ownership. We also find that a higher degree of "foreignness," represented by a larger share of foreign equity or a wholly owned registration status, is associated with a bigger VAT discount. In general, our results validate - but do so more rigorously - the existing research on foreignownership biases.

We also find evidence that foreign-ownership biases are less pronounced in capital- and skillintensive sectors, contrasting conventional wisdom that preferential treatments for foreign firms are designed to maximize welfare and economic growth. Together with the patterns observed across provinces, our findings offer prima facie evidence to support the hypothesis that the biased policies in China might have been grounded on political concerns rather than welfare-maximizing motives.

There is some suggestive evidence in support of a residual hypothesis - the one that has political economy, rather than economics, as the likely reason for the observed VAT biases. The patterns of correlations between the degree of VAT discount and the output shares of SOEs and domestic private firms in Figure $3 a$ and $b$ suggest that the VAT biases depend on the performance and the weight of SOEs, not those of domestic private firms.

Our conjecture is that a political pecking order of firms - SOEs at the top and domestic private firms at the bottom with FIEs in between - is consistent with the observed pattern. The VAT enforcement is used in accordance with this political pecking order of firms. Specifically, in provinces with high SOE output shares, the government enforces VAT on FIEs in greater fidelity to the statutory levels. This may have the effect of curbing their competitiveness vis-à-vis SOEs. Since the government is indifferent to the domestic private firms, the VAT treatments of FIEs do not vary with the provincial shares of output by the domestic private firms. We arrive at this conclusion by deduction and on the basis of suggestive evidence. We hope that future researchers will explore this topic in greater depth.

\section{NOTES}

${ }^{1}$ Quoted by McGregor and Sun (2006).

${ }^{2}$ See Collier and Dollar (2001) and Dollar (2005).

${ }^{3}$ See Huang (2003), among others.

${ }^{4}$ The literature on liability of foreignness is vast. For a treatment of the topic in a context of institutions, see Eden and Miller (2004).

${ }^{5}$ There is an analogous, although smaller, literature in economics known as "national preference hypothesis." The "national preference hypothesis" describes a phenomenon whereby governments often implement preferential regulations and policies to protect domestic businesses from foreign competition. An important reason is that FIEs are less politically influential than domestic firms for the host government, especially in democratic systems where politicians derive electoral benefits by maximizing votes. Foreign investors do not vote (Caves, 1996). 
${ }^{6}$ Moreover, Chinese FIEs are also allowed to offset their tax liabilities with accumulated operating losses rather than only current losses. The loss carryovers cover a period of 5 years.

7Using survey data from the World Bank's World Business Environment Survey for 80 countries in 19992000, Huang (2005) and Desbordes and Vauday (2007) find that FIEs have more political influence on host governments than domestic private firms. The higher level of political influence is inferred from fewer self-reported constraints on their businesses along several dimensions, including taxes and regulations. They also explore a number of country-level and firmlevel characteristics that affect the degree of FIE political influence.

${ }^{8}$ One may argue that since foreign firms on average are more export-oriented, this correlation simply reflects a potential reverse causal relationship - more pro-foreign VAT collection attracts more exporting firms to the province. In the regression analyses below, we use measures of lagged export orientation to circumvent this potential endogeneity problem.

${ }^{9}$ See Holger and Greenway (2004) for an extensive review of the vast literature on FDI spillovers.

${ }^{10}$ Among these studies, a pioneering study by Caves (1974) finds a positive relationship between the output share of foreign firms and the average productivity across Australian manufacturing industries in the 1960s. Blomstrom and Wolff (1994) find that in Mexico, productivity growth and convergence to the productivity frontier of US affiliates were faster in manufacturing sectors with a higher penetration of multinationals.

${ }^{11}$ Among them, Haddad and Harrison (1993) find no significant relationship between the level of FDI and domestic-plant productivity growth in the same sector for Morocco in the late 1980s; Aitken and Harrison (1999) find a negative relationship between the two for Venezuelan manufacturing industries in the 1970s and 1980s, followed by similar findings in the 1990 s by Djankov and Hoekman (2000) for the Czech Republic and Konings (2001) for Bulgaria and Romania; Konings (2001) finds no spillovers to domestic firms for Poland, while Javorcik (2004) finds positive spillover along the domestic supply chains for Lithuania. The authors of this literature suggest the possibility of negative efficiency spillovers arising from foreign firms stealing market shares from domestic firms. Although the findings for developed countries are more likely to show positive FDI spillovers, a comprehensive review by Görg and Greenway (2004) shows that among twenty-four firm-level panel studies, only five of them find positive spillovers, of which four are from developed countries.

${ }^{12}$ The number of firms SOE grew from about 160,000 firms in 1998 to over 260,000 firms in 2005.

${ }^{13}$ See Brandt, Van Biesebroeck, and Zhang (2009) for a detailed description.

${ }^{14} \mathrm{~A}$ reason for imposing a minimum employment threshold is that very small firms sometimes pay only $6 \%$ of the VAT tax base. It should be noted, however, that the vast majority of small firms are already excluded from the dataset because they do not meet the 5-million-yuan qualifying threshold imposed by NBSC.

${ }^{15}$ The key variables include product sales, industrial output (current prices), total assets, liquid assets, intermediate inputs, accumulated depreciation, and current depreciation. We dropped about 3,800 observations from the panel that have negative values for these variables.

${ }^{16}$ The numbers of observations for each year are 157,633 (1998), 154,957 (1999), 155,631 (2000), 160,028 (2001), 174,682 (2002), 188,775 (2003), 268,030 (2004), and 259,768 (2005). The balanced panel contains 40,398 unique firms (firms that are present in all 8 years).

${ }^{17}$ See Liu (2006) for detailed descriptions of the VAT in chapter 3, and Ferrantino, Liu, and Wang (2012) and Chandra and Long (2013) for more discussions. Observations with negative de facto VAT rates are excluded from our sample.

${ }^{18}$ The dataset contains data on the firms' gross output, both in current and constant prices, and valueadded only in current prices. A firm's constant-price output is constructed using a set of "reference" prices recommended by the NBSC (see Data Appendix for the construction of the output deflators).

${ }^{19}$ The procedure of winsorizing data to enhance data quality has become a common practice in empirical studies using firm-level data from developing countries. See, for example, Kugler and Verhoogen (2008) who use firm-level data from Colombia. Importantly, the results of regressions using the nonwinsorized sample are qualitatively the same.

${ }^{20}$ Since the VAT is non-negative and smaller than 1 , one can argue that the dependent variable is both leftcensored (at 0) and right censored (at 1) and that the OLS estimates are biased. Alternatively, we can estimate specification (1) using a Tobit model. In unreported results, we estimate (1) using a Tobit model. All results remain qualitatively the same. A reason why we estimate (1) using OLS is that fixed-effects Tobit estimates over a short panel are inconsistent. See 
Cameron and Trivedi (2005: 800-801) for a technical discussion.

${ }^{21}$ One reason might be that the government would want to be stricter in enforcing laws for larger firms than smaller firms because of its intention to maximize tax revenue or to signal to other firms its commitment to collect taxes. Older firms might be more concerned about survival and reputation, and therefore are more likely to closely abide by the law.

\section{REFERENCES}

Aitken, B. J., \& Harrison, A. E. 1999. Do domestic firms benefit from direct foreign investment? American Economic Review, 89(3): 605-619.

Blomstrom, M., \& Wolff, E. N. 1994. Multinational corporations and productivity convergence in Mexico. NBER Working Paper No. 3141.

Brandt, L., Van Biesebroeck, J., Zhang, Y. 2009. Creative accounting or creative destruction? Firm-level productivity growth in Chinese manufacturing. NBER Working Paper No. 15152.

Branstetter, L., \& Feenstra, R. C. 2003. Trade and foreign direct investment in China: A political economy approach. Journal of International Economics, 58(2): 335-358.

Cameron, C. A., \& Trivedi, P. K. 2005. Microeconometrics: Methods and applications. New York: Cambridge University Press.

Caves, R. E. 1974. Multinational firms, competition, and productivity in host-country markets. Economica (New Series), 41(162): 176-193.

Caves, R. E. 1996. Multinational enterprise and economic analysis (2nd ed.). New York: Cambridge University Press.

Chandra, P., \& Long, C. 2013. VAT rebates and export performance in China: Firm-level evidence. Journal of Public Economics, 102: 13-22.

Chari, A., \& Gupta, N. 2008. Incumbents and protectionism: The political economy of foreign entry liberalization. Journal of Financial Economics, 88(3): 633-656.

Collier, P., \& Dollar, D. 2001. Can the world cut poverty in half? How policy reform and effective aid can meet international development goals. World Development, 29(11): 1787-1802.

Defever, F., \& Riaño, A. 2017. Subsidies with export share requirements in China. Journal of Development Economics, 126: $33-51$.

Desbordes, R., \& Vauday, J. 2007. The political influence of foreign firms in developing countries. Economics and Politics, 19(3): 421-451.

Djankov, S., \& Hoekman, B. 2000. Foreign investment and productivity growth in Czech enterprises. World Bank Economic Review, 14(1): 49-64.

Dollar, D. 2005. Globalization, poverty, and inequality since 1980. World Bank Research Observer, 20(2): 145-175.

Dollar, D., \& Wei, S.-J. 2007. "Das (Wasted) kapital: Firm ownership and investment efficiency in China. NBER Working Paper 13103 (May).

Eden, L., \& Miller, S. R. 2004. Distance matters: Liability of foreignness, institutional distance and ownership strategy. In M. A. Hitt \& J. L. C. Cheng (Eds), Theories of the multinational enterprise: Diversity, complexity and relevance: 187-221. London: Emerald Group Publishing.

Ferrantino, M., Liu, X., \& Wang, Z. 2012. Evasion behaviors of exporters and importers: Evidence from the US-China trade data discrepancy. Journal of International Economics, 86(1): 141-157.
${ }^{22}$ It is well known that decision rights for economic policies are decentralized to the provincial governments. See Li and Zhou (2004).

${ }^{23}$ The point estimate on the interaction term is 0.126 . The differential impact is computed by $0.126^{*}(0.5-0.25)=0.0315$.

Görg, H., \& Greenway, D. 2004. Much Ado about nothing? Do domestic firms really benefit from foreign direct investment? World Bank Research Observer, 19(2): 171-197.

Gourdon, J., Hering, L., Monjon, S., \& Poncet, S. 2014. Incomplete VAT rebates to exporters: How do they affect China's export performance? CEPII Working Paper 2014-05.

Grossman, G. M., \& Helpman, E. 1994. Protection for sale. American Economic Review, 84(4): 833-850.

Grossman, G. M., \& Helpman, E. 1996. Foreign investment with endogenous protection. In R. C. Feenstra, G. M. Grossman, \& D. A. Irwin (Eds), The political economy of trade policy (Chap 10). Cambridge: MIT Press.

Guariglia, A., \& Poncet, S. 2008. Could financial distortions be no impediment to economic growth after all? Evidence from China. Journal of Comparative Economics, 36(4): 633-657.

Haddad, M., \& Harrison, A. 1993. Are there positive spillovers from direct foreign investment? Evidence from panel data for Morocco. Journal of Development Economics, 42(1): 51-74.

Holger, G., \& Greenway, D. 2004. Much ado about nothing? Do domestic rms really benefit from foreign direct investment? World Bank Research Observer, 19: 171-197.

Hsieh, C.-T., \& Klenow, P. J. 2009. Misallocation and manufacturing TEP in China and India. Quarterly Journal of Economics, 124(4): 1403-1448.

Huang, Y. 2003. Selling China: Foreign direct investment during the reform era. New York: Cambridge University Press.

Huang, Y. 2005. Are foreign firms privileged by their host governments? Evidence from the 2000 World Business Environment Survey. MIT Working Paper No. 4538-04.

Huang, Y, Ma, Y., Yang, Z., \& Zhang Y. 2016. A fire sale without fire: An explanation of labor intensive FDI in China. Journal of Comparative Economics, 44: 884-901.

Javorcik, B. S. 2004. Does foreign direct investment increase the productivity of domestic firms? The search for spillovers through backward linkages. American Economic Review, 94(3): 605-627.

Kokko, A. 1996. Productivity spillovers from competition between local firms and foreign affiliates. Journal of International Development, 8(4): 517-530.

Konings, J. 2001. The effects of foreign direct investment on domestic firms: Evidence from firm-level panel data in emerging economies. Economics of Transition, 9(3): 619-633.

Kugler, M., \& Verhoogen, E. 2008. The quality-complementarity hypothesis: Theory and evidence from Colombia. NBER Working Paper No. 14418.

Li, H., \& Zhou, L.-A. 2004. Political turnover and economic performance: The incentive role of personnel control in China. Journal of Public Economics, 89(9-10): 1743-1762.

Liu, Z. 2006. Taxation in China. Singapore: Thomson Learning.

McGregor, R., \& Sun, Y. 2006. Challenging change: Why an ever fiercer battle hinders China's march to the markets. Financial Times, February 28. 
National Bureau of Statistics of China. 1996. The Third National Industrial Census.

National Bureau of Statistics of China. 1999-2006. China's statistical yearbook, various issues.
Zaheer, S. 1995. Overcoming the liability of foreignness. The Academy of Management Journal, 38(2): 341-363.

\section{DATA APPENDIX}

We use the ratio of a firm's current-price output to constant-price output as the firm's implicit output deflator. We then use the firm's output deflator to calculate its inflation rate between two consecutive years. For a given year, the sectoral inflation rate is then constructed using the weighted average of the firms' inflation rates within the same sector, with weights equal to the firms' output shares in that sector. In constructing the sectoral inflation rates, we exclude firm-specific inflation rates that are 1 standard deviation or more away from the mean of the sector in that year. Finally, using 1998 as the base year, we use the sectoral inflation rates to calculate sector-specific output deflators for 7 years (1999-2005) and 33 two-digit sectors. For observations for the years between 1998 and 2002, we use the sector-specific output deflators to deflate firm nominal value-added and nominal output to obtain the corresponding real values. For observations from 2003 and later, we use the ex-factory price indices of industrial products at the two-digit sector level from China's Statistical Yearbook (20042006). These are not publicly available for before 2003. See Tables A1, A2, and A3.

Table A1 Firm-level summary statistics

\begin{tabular}{|c|c|c|c|c|c|c|c|c|}
\hline & $\begin{array}{l}\text { Num. } \\
\text { obs. }\end{array}$ & $10 \%$ & $25 \%$ & $50 \%$ & $75 \%$ & $90 \%$ & Mean & $\begin{array}{l}\text { Standard } \\
\text { dev. }\end{array}$ \\
\hline Effective (de facto) VAT rate & $1,335,397$ & 0 & $3.54 \%$ & $11.11 \%$ & $18.99 \%$ & $28.24 \%$ & $13.47 \%$ & $13.24 \%$ \\
\hline Foreign firm dummy & $1,423,054$ & 0 & 0 & 0 & 0 & 1 & 0.21 & 0.40 \\
\hline Output (constant 98 mn yuan) & $1,378,586$ & 39.25 & 72.86 & 149.67 & 360.54 & 907.12 & 585.27 & 4625.10 \\
\hline Value-added (constant $98 \mathrm{mn}$ yuan) & $1,337,947$ & 7.60 & 17.75 & 38.62 & 95.98 & 245.74 & 156.92 & 1274.65 \\
\hline Employment & $1,423,054$ & 26 & 52 & 110 & 240 & 517 & 261.11 & 844.48 \\
\hline Fixed asset (constant $98 \mathrm{mn}$ yuan) & $1,420,719$ & 4.24 & 12.70 & 36.82 & 113.06 & 351.12 & 238.25 & 2442.29 \\
\hline Age & $1,417,781$ & 1 & 3 & 6 & 13 & 29 & 10.54 & 11.58 \\
\hline Worker share (in province-sector-year cell) & $1,315,737$ & $0.09 \%$ & $0.26 \%$ & $0.90 \%$ & $3.39 \%$ & $12.44 \%$ & $5.56 \%$ & $14.70 \%$ \\
\hline $\begin{array}{l}\text { Value-added share (in province-sector-year } \\
\text { cell) }\end{array}$ & $1,319,556$ & $0.05 \%$ & $0.18 \%$ & $0.68 \%$ & $2.95 \%$ & $12.50 \%$ & $5.61 \%$ & $15.42 \%$ \\
\hline Exporter dummy & $1,423,054$ & 0 & 0 & 0 & 1 & 1 & 0.27 & 0.44 \\
\hline
\end{tabular}

Notes: The firm-level sample includes firms that satisfy the 5 million RMB threshold in each reporting year for the 1998-2005 period. The summary statistics are calculated after the extreme outliers in output, value-added, fixed assets, and age are "winsorized" at the 1 and 99 percentiles. Source: National Bureau of Statistics of China, Annual Survey of Industrial Firms (sample pooled over 1998-2005).

Table A2 Sector-level summary statistics

\begin{tabular}{|c|c|c|c|c|c|c|c|c|}
\hline & Num. obs. & $10 \%$ & $25 \%$ & $50 \%$ & $75 \%$ & $90 \%$ & Mean & Standard dev \\
\hline Capital intensity (real capita/real sales) & 176 & 0.134 & 0.169 & 0.225 & 0.334 & 0.515 & 0.341 & 0.480 \\
\hline Skill intensity 1 (high-school workers/workforce) & 176 & 0.328 & 0.367 & 0.473 & 0.554 & 0.682 & 0.479 & 0.130 \\
\hline Skill intensity 2 (college workers/workforce) & 176 & 0.045 & 0.054 & 0.119 & 0.173 & 0.254 & 0.135 & 0.082 \\
\hline$R \& D$ intensity (R\&D expenditure/sales) & 176 & 0.000 & 0.000 & 0.002 & 0.009 & 0.018 & 0.006 & 0.010 \\
\hline
\end{tabular}

Notes: The capital and the two skill intensity measures are calculated using firm-level data from China's National Bureau of Statistics 2004 Census of Industrial Firms. The R\&D intensity measures are calculated using firm-level data from the National Bureau of Statistics 2005 Industrial Firm Survey, the year for which data on R\&D expenditures are available. All measures therefore are time-invariant Source: National Bureau of Statistics of China, Annual Survey of Industrial Firms (various years). 
Table A3 Province-level summary statistics

\begin{tabular}{|c|c|c|c|c|c|c|}
\hline Province & $\begin{array}{l}\text { Mean FIE } \\
\text { VATR }\end{array}$ & $\begin{array}{c}\text { Avg domestic private } \\
\text { VATR }\end{array}$ & $\begin{array}{l}\text { Avg. SOE } \\
\text { VATR }\end{array}$ & $\begin{array}{l}\text { SOE VA } \\
\text { share }\end{array}$ & $\begin{array}{c}\text { Domestic private VA } \\
\text { share }\end{array}$ & $\begin{array}{l}\text { Export/ } \\
\text { sales }\end{array}$ \\
\hline Anhui & 13.68 & 13.26 & 12.57 & 36.63 & 42.14 & 8.07 \\
\hline Beijing & 17.21 & 17.39 & 16.04 & 36.01 & 21.96 & 10.74 \\
\hline Chongqing & 17.01 & 18.21 & 16.09 & 32.75 & 45.51 & 5.82 \\
\hline Fujian & 10.13 & 11.66 & 11.66 & 16.55 & 20.97 & 35.05 \\
\hline Gansu & 12.75 & 12.67 & 11.64 & 55.20 & 29.97 & 3.18 \\
\hline Guangdong & 8.83 & 10.40 & 11.09 & 11.83 & 23.57 & 40.61 \\
\hline Guangxi & 15.63 & 17.75 & 16.52 & 44.50 & 32.27 & 6.77 \\
\hline Guizhou & 17.52 & 16.92 & 16.63 & 66.05 & 27.02 & 3.63 \\
\hline Hainan & 19.60 & 16.56 & 18.39 & 33.82 & 45.82 & 5.35 \\
\hline Hebei & 12.12 & 12.44 & 11.01 & 33.77 & 38.58 & 6.32 \\
\hline Heilongjiang & 14.98 & 16.65 & 15.88 & 43.54 & 38.36 & 2.93 \\
\hline Henan & 11.61 & 10.62 & 9.87 & 37.27 & 35.76 & 4.44 \\
\hline Hubei & 11.91 & 11.20 & 10.58 & 37.06 & 37.28 & 4.59 \\
\hline Hunan & 14.21 & 13.77 & 13.37 & 53.15 & 30.62 & 6.08 \\
\hline Jiangsu & 13.44 & 14.23 & 14.38 & 16.84 & 38.71 & 21.40 \\
\hline Jiangxi & 10.65 & 11.89 & 11.93 & 50.19 & 33.20 & 5.62 \\
\hline Jilin & 12.76 & 14.05 & 12.54 & 42.79 & 27.96 & 3.31 \\
\hline Liaoning & 10.77 & 14.66 & 14.48 & 38.41 & 32.02 & 16.40 \\
\hline Inner & 12.58 & 13.58 & 12.28 & 41.29 & 46.48 & 5.75 \\
\hline \multicolumn{7}{|l|}{ Mongolia } \\
\hline Ningxia & 13.53 & 16.70 & 14.50 & 42.63 & 44.60 & 8.76 \\
\hline Qinghai & 13.35 & 14.38 & 13.47 & 43.21 & 50.77 & 4.11 \\
\hline Shaanxi & 15.18 & 14.03 & 13.19 & 49.92 & 31.02 & 4.97 \\
\hline Shandong & 10.84 & 11.47 & 11.38 & 22.65 & 40.27 & 14.34 \\
\hline Shanghai & 12.35 & 14.84 & 15.02 & 19.58 & 22.90 & 23.86 \\
\hline Shanxi & 15.82 & 16.37 & 16.54 & 41.63 & 42.37 & 3.98 \\
\hline Sichuan & 14.03 & 15.51 & 13.89 & 36.56 & 51.12 & 5.35 \\
\hline Tianjin & 14.43 & 15.59 & 14.89 & 20.34 & 19.43 & 24.38 \\
\hline Tibet & 3.43 & 7.97 & 6.14 & 49.03 & 32.84 & 0.49 \\
\hline Xinjiang & 15.76 & 19.47 & 17.12 & 37.95 & 54.39 & 4.06 \\
\hline Yunnan & 19.36 & 20.36 & 20.56 & 72.43 & 19.65 & 4.20 \\
\hline Zhejiang & 13.96 & 15.64 & 16.35 & 14.81 & 55.08 & 24.81 \\
\hline
\end{tabular}

Notes: Numbers are in \%.

Source: National Bureau of Statistics of China, Annual Survey of Industrial Firms (sample pooled over 1998-2005).

\section{ABOUT THE AUTHORS}

Yasheng Huang is an International Program Professor in Chinese Economy and Business and a Professor of Global Economics and Management at the MIT Sloan School of Management. His research interests focus on international business, political economy, international management, entrepreneurship, and economic and political history of China. He is founder of China Lab and India Lab at MIT.

Heiwai Tang is an Assistant Professor of International Economics at the Johns Hopkins School of Advanced International Studies. His research interests span a wide range of theoretical and empirical topics in international trade, including how offshoring affects the domestic buyer-supplier networks; how firms learn from their neighbors to export; and how China successfully moved up the global value chains.

Open Access This article is distributed under the terms of the Creative Commons Attribution 4.0 International License (http://creativecommons.org/ licenses/by/4.0/), which permits unrestricted use, distribution, and reproduction in any medium, provided you give appropriate credit to the original author(s) and the source, provide a link to the Creative Commons license, and indicate if changes were made. 